\title{
ЛІНГВІСТИЧНА КОМПЕТЕНТНІСТЬ ЯК СКЛАДНИК ПРОФЕСІЙНОЇ КОМПЕТЕНТНОСТІ ФІЛОЛОГА
}

Монашненко А. М. Лінгвістична компетентність як складник професійної компетентності філолога.

У статті розглядаються різні визначення терміна «компетентність» та його складники. Досліджується лінгвістична компетентність як складник професійної компетентності студентів-філологів.

Ключові слова: компетентність, професійна компетентність, лінгвістична компетентність.

Монашненко А. М. Лингвистическая компетентность как составляющая профессиональной компетентности филологов.

В статье рассматриваются различные определения термина «компетентность» и его составляющие. Исследуется лингвистическая компетентность как составляющая профессиональной компетентности студентов-филологов.

Ключевые слова: компетентность, профессиональная компетентность, лингвистическая компетентность.

Monashnenko A. M. Linguistic competence as a component of professional competence of philologists.

The article discusses various definitions of the term "competence" and its components. We investigate linguistic competence as a component of professional competence of students-philologists.

Keywords: competence, professional competence, linguistic competence.

Основною задачею для вищих навчальних закладів $€$ виховання студентів 3 високим рівнем знань, які зможуть оперувати отриманими знаннями. Засвоєння студентами-філологами іноземних мов $\epsilon$ запорукою високої конкурентоспроможності на ринку праці. Формування професійної компетентності майбутніх фахівців є складним та об'ємним процесом навчання. Лінгвістична компетентність $є$ складником професійної компетентності філологів та відіграє важливу роль у сприйнятті та засвоєнні студентами іноземної мови. Тому ниныі проблема формування лінгвістичної компетентності у студентів-філологів $\epsilon$ важливою й актуальною.

Компетентність розглядається як категорія, що характеризує знання та вміння людини. Компетентність - це стійка готовність і здатність людини до діяльності зі «знанням справи» [6, с. 1]. Поняття компетентність розглядається у працях I. Зязюна, В. Сластьоніна, В. Нестерова, Л. Станкевич та ін.

Mema cmammi полягає в теоретичному обгрунтуванні поняття лінгвістичної компетентності як складника професійної компетентності студентів-філологів.

Поняття «компетентність» науковці трактують по-різному, вкладаючи різний зміст і досліджуючи особливості професійних функцій, що є специфічними для певного фаху. Уведення в лексику терміна «компетентність» обгрунтовано в 80-х роках зарубіжними науковцями (Р. Бадер, Д. Мертенс, Б. Оскарсон, А. Шелтен, Саймон Шо та ін.) [3, с. 21]. В Україні термін «компетентність» поступово набув 
поширення в сенсі реалізацій знання, умінь і навичок, але однозначне визначення сутності компетентності як педагогічної категорії у літературі відсутнє.

У великому тлумачному словнику сучасної української мови компетентність трактується як якість, що пов'язана 3 достатнім рівнем знань у певній галузі (В. Бусел) [2, с. 977]. Словник професійної освіти визначає компетентність (від. лат. competo - відповідний, підхожий) як сукупність знань і вмінь, необхідних для ефективної професійної діяльності: уміння аналізувати, передбачати наслідки професійної діяльності, використовувати інформацію (С. Гончаренко) [9, с. 235]. У державних галузевих стандартах вищої освіти компетентність визначається як необхідний обсяг і рівень знань, досвід із певного виду діяльності, наголошується, що фахова компетентність характеризує якість особистості випускника вищого навчального закладу, під якою розуміють «цілісну сукупність характеристик особистості, що визначає зміст соціально значущих i професійно важливих властивостей особи, яка закінчує вищий навчальний заклад» [3, с. 34].

В. Ландшеєр [7, с. 44] зазначає, що компетентність характеризує такий рівень навченості, який потрібен громадянину для успішного функціонування у суспільстві. Компетентність, на думку В. Стрельникова $[11$, с. 46], - це глибокі знання, реальна професійна діяльність згідно 3 установленими еталонами та нормативами, а також володіння необхідними для цієї діяльності психологічними якостями. Професійна компетентність, на думку В. Адольфа, І. Степанової [1, с. 57], виявляється у різних видах діяльності спеціаліста, що дозволяє йому почувати себе комфортно в суспільстві. Розвинуте професійне мислення характеризується як основна ознака професійної компетентності фахівців.

Останнім часом поняття компетентності викликало широку дискусію 3-поміж країн-учасників Організації економічного співробітництва та розвитку (OECD), Міжнародних документах Європи, Міжнародної організації праці, де проводились дослідження в більшості європейських країн 3 даної проблематики. Програма ставить акценти, наголошуючи, що ключові компетентності (key competencies) надають змогу особистості ефективно брати участь у багатьох соціальних сферах, роблять внесок в розвиток якості суспільства та особистого успіху, отже, можуть бути застосованими до багатьох життєвих галузей [3, с. 56].

I. Кухта [6, с. 2] зазначає такі узагальнення тлумачення компетентності:

- завше розглядається у контексті професійної діяльності;

- розуміється як інтегративне утворення особистості, що становить сукупність різних компетенцій людини;

- характеризує рівень готовності людини до діяльності, а також характер та ефективність її здійснення;

- формується у процесі засвоєння людиною відповідної для неї діяльності.

Ю. Поваренков [8, с. 34] обгрунтовує три узагальнені критерії професійної компетентності фахівців: 1) професійна продуктивність - характеризує рівень професіоналізму людини, його відповідність соціально-професійним вимогам суспільства; 2) професійна ідентичність - розкриває значущість для людини професійної діяльності як засобу задоволення власних потреб, розвитку особистісного потенціалу; 3) професійна зрілість - відображує вміння людини співвідносити власні професійні можливості та потреби 3 професійними вимогами. У цьому зв'язку, на думку автора, важливими $є$ професійна самооцінка, рівень домагань, здатність до саморегуляції.

У дослідженні В. Журавльова [4, с. 67] запропоновано три групи стандартів професійної компетентності: 1) професійно-діяльнісні- ступінь оволодіння 
професійними знаннями; 2) рефлексивні - самооцінні та зовнішньооцінні, зокрема, володіння технікою інтроспекції, 3) володіння знаннями про здоровий образ життя, озброєння засобами соціального та психологічного захисту від впливу несприятливих факторів професії.

Поняття «компетентність» має складний зміст, оскільки охоплює різні сторони особистості. Саме лінгвістична компетентність відповідає за мовну сферу фахівця: граматично правильну побудову речень іноземною мовою, правильність написання та вимови складних лексичних конструкцій, вміння вдало висловити свої думки та враження від тексту, фільму, відеоролика тощо, вміння аналізувати та оцінювати зміст тексту.

Лінгвістична компетентність $є$ складником професійної компетентності та становить систему засвоєних знань студентом-філологом та вияв їх у мовленнєвій діяльності.

Психолог Б. Ломов стверджує, що в будь-якій ситуації, яка вимагає мовленнєво-мисленнєвої діяльності, взаємодіють три складники: поставлена проблема, наявні для їі розв'язання знання, дослідницькі дії. Ці складники реалізуються на уроках іноземної мови у вищих навчальних закладах у формі уроку-дискусії, уроку монологічного й діалогічного мовлення й уроку з ігровими завданнями.

С. Корнієнко [5, с. 163] виокремлює основні компоненти лінгвістичної компетентності:

1) знання щодо мовних одиниць і правил їх поєднання;

2) правила творення граматичних форм;

3) обсяг і точність володіння лінгвістичними компонентами;

4) здібність будувати речення за допомогою засвоєних мовних умінь.

Вище зазначені компоненти лінгвістичної компетентності $€$ основними критеріями оволодіння студентами-філологами іноземною мовою, правильності побудови речень, збагачення лексичного запасу, формування здібностей щодо аналізу і оцінки мовних фактів.

Отже, лінгвістична компетентність передбачає набуття знань студентамифілологами з іноземної мови, засвоєння їх, розвиток і збільшення лексичного запасу слів, володіння орфографічними й пунктуаційними нормами.

У перспективі $є$ доцільним розроблення методів формування лінгвістичної компетентності у філологів.

\section{Література}

1. Адольф В. А. Обновление процесса подготовки педагогов на основе моделирования профессиональной деятельности: монографія / В. А. Адольф, I. Ю. Степанова. - Красноярск, 2005. - 214 с. 2. Великий тлумачний словник сучасної української мови / [уклад. та голов. ред. В. Т. Бусел]. - К., Ірпінь : Перун, 2001. - 1440 с. 3. Вікторова Л. В. Формування професійно-термінологічної компетентності студентів вищих аграрних навчальних закладів у фаховій підготовці: дис... канд. наук: 13.00.04 / Л. В. Вікторова. - 2009. - 24 с. 4. Журавлев В. И. Основы педагогической конфликтологии: учебник. - М.: Российское педагогическое агентство, 1995. - 184 с. 5. Корніснко С. І. Сутність і основні характеристики лінгвістичної компетентності майбутніх вчителів болгарської мови / С. І. Корнієнко // Педагогічні науки. - Вип. 4. - Бердянськ, 2009. - C. 161-165. 6. Кухта I. В. Іншомовна компетентність у контексті формування комунікативної культури студентів у процесі вивчення іноземної мови [Електронный ресурс]. - Режим доступу: 
http://visnyk.vntu.edu.ua/article/view/608/1847

7. Ландшеер В.

Концепция

«минимальной компетентности»/ В. Ландшеер // Перспективы. Вопросы образования. - 1988. - № 1/5. - С. 44-48. 8. Поваренков Ю. П. Психологическое содержание профессионального становления человека / Ю. П. Поваренков. - М.: Изд-во УРАО, 2002. - 212 с. 9. Професійна освіта: словник: навч. посіб. / [уклад. С. У. Гончаренко та ін.]; за ред. Н. Г. Ничкало. - К. : Вища школа, 2000. - 380 с. 10. Степашкина Л. Ю. Развитие общих учебных умений и навыков как ключевой образовательной компетенции [Електронний ресурс] / Л. Ю. Степашкина // Интернет-журнал «Эйдос». - 2005. - Режим доступу: http://www.eidos.ru/journal/2005/0910-09.htm 11. Стрельников В. Ю. Розвиток професійної компетентності вчителів у закладах післядипломної освіти: дис... канд. пед. Наук / В. Ю. Стрельников. - Київ, 1995. - 223 с. 12. Хуторской А. В. Ключевые компетенции и образовательные стандарты [Электронный ресурс] / А. В. Хуторской. - Режим доступу: http://eidos.ru/journal/2002/0423.htm

\section{УДОСКОНАЛЕННЯ ЛЕКСИЧНИХ УМІНЬ І НАВИЧОК СТУДЕНТІВ У ПРОЦЕСІ НАВЧАННЯ УКРАЇНСЬКОЇ МОВИ (ЗА ПРОФЕСІЙНИМ СПРЯМУВАННЯМ)}

Пасічна О. В.Удосконалення лексичних умінь і навичок студентів у процесі навчання української мови (за професійним спрямуванням).

У статті обгрунтовується необхідність застосування системи тренувальних вправ задля вдосконалення лексичних умінь i навичок студентів у сфері професійного спілкування. Запропонована система роботи дозволяє розширити словниковий запас студентів та попередити виникнення лексичних помилок.

Ключові слова: професійна комунікація, лексична компетенція, лексична помилка, тренувальні вправи, синоніми, пароніми, омоніми.

Пасечная Е. В. Усовершенствование лексических учений и навыков студентов в процессе обучения украинскому языку (по профессиональному направлению).

В статье обосновывается необходимость применения системы тренировочных упражнений для усовершенствования лексических умений и навыков студентов в сфере профессионального общения. Предложенная система работы позволяет расширить словарный запас студентов и предупредить появление лексических ошибок.

Ключевые слова: профессиональная коммуникация, лексическая компетенция, лексическая ошибка, тренировочные упражнения, синонимы, паронимы, омонимы.

Pasichna O. V. Improvement of the lexical skills of students in learning the Ukrainian language (for professional purposes).

In the paper the necessity of application of the system of training exercises to improve vocabulary skills of students in the field of professional communication is considered. The proposed system allows students to expand vocabulary and prevent the occurrence of lexical errors.

Key words: professional communication, lexical competence, lexical error, training exercises, synonyms, paronyms, homonyms. 